\title{
PENERAPAN MODEL PEMBELAJARAN ROLE PLAYING TERHADAP PENINGKATAN AKTIVITAS BELAJAR SISWA PADA MATA PELAJARAN BAHASA INGGRIS DI KELAS IX SMP NEGERI 2 PANYABUNGAN
}

\author{
Siti Fatimah \\ Guru SMP Negeri 2 Panyabungan \\ Surel : Siti_fatimah@yahoo.co.id
}

\begin{abstract}
Abstrak
Penelitian ini bertujuan untuk mengetahui apakah terdapat peningkatan aktivitas belajar dan hasil belajar bahasa Inggris siswa, khususnya Slice the Onion Please dengan penerapan model pembelajaran Role Playing.

Hasil belajar siswa dengan menerapkan model pembelajaran Role Playing pada Formatif I menunjukkan 10 orang siswa tuntas secara individu, persentase ketuntasan dalam kelas $41,67 \%$. Pada Siklus II, tuntas secara individu sebanyak 21 orang siswa, sedangkan persentase ketuntasan klasikal yaitu 87,50\%. Dengan nilai rata-rata pada siklus I adalah 64,2 dan pada siklus II adalah 80,83. Data aktivitas siswa menurut kedua pengamatan pengamat pada Siklus I antara lain: menulis/membaca (38\%), bekerja (31\%), bertanya sesama teman (21\%), bertanya kepada guru (5\%), dan yang tidak relevan dengan KBM (5\%). Data aktivitas siswa menurut pengamatan pada Siklus II antara lain: menulis/membaca (30\%), bekerja (38\%), bertanya sesama teman (23\%), bertanya kepada guru (7\%), dan yang tidak relevan dengan $\mathrm{KBM}(3 \%)$.
\end{abstract}

Kata Kunci : Model, Role Playing

\section{PENDAHULUAN}

Dalam perkembangan intelektual, sosial dan emosional peserta didik bahasa memiliki peran sentral dan merupakan penunjang keberhasilan dalam mempelajari semua bidang studi pembelajaran bahasa diharapkan membantu peserta didik mengenal dirinya, budayanya, dan budaya orang lain. Selain itu, pembelajaran bahasa juga membantu peserta didik mampu mengemukakan gagasan dan perasaan, berpartisipasi dalam masyarakat dan bahkan menemukan serta kemampuan analisis dan imajinatif yang ada dalam dirinya.

Bahasa Inggris merupakan alat untuk berkomunikasi secara lisan dan tulisan. Berkomunikasi adalah memahami dan mengungkapkan informasi pikiran, perasaan dan mengembangkan ilmu pengetahuan teknologi dan budaya. Kemampuan berkomunikasi dalam pengertian yang utuh adalah kemampuan berwacana, yakni kemampuan memahami dan menulis direalisasikan dalam empat keterampilan berbahasa, yaitu mendengarkan, berbicara, membaca dan menulis. Keempat keterampilan inilah yang digunakan untuk menanggapi atau menciptakan wacana dalam kehidupan bermasyarakat. Oleh karena itu, mata pelajaran bahasa Inggris diarahkan untuk mengembangkan keterampilanketerampilan tersebut. Agar lulusan Sekolah Menengah Pertama mampu 
berkomunikasi dan berwacana dalam bahasa Inggris pada tingkat literasi tertentu.

Performative, functional, informational dan epistemic merupakan cakupan tingkat literasi. Pada tingkat performative, orang mampu membaca, menulis, mendengarkan dan berbicara dengan simbol-simbol yang digunakan. Pada tingkat functional, orang mampu menggunakan bahasa untuk memenuhi kebutuhan hidup sehari-hari seperti membaca surat kabar, manual dan petunjuk. Pada tingkat informational, orang mampu mengakses pengetahuan dengan kemampuan berbahasa, sedangkan pada tingkat epistemic orang mampu mengungkapkan pengetahuan ke dalam bahasa sasaran (Wells, 1987).

Pembelajaran bahasa Inggris di SMP diharapkan dapat mencapai tingkat informational karena mereka disiapkan untuk melanjutkan pendidikannya ke perpenelitian tinggi tingkat literasi epistemic dianggap terlalu tinggi untuk dapat dicapai oleh peserta didik SMP karena bahasa Inggris di Indonesia berfungsi sebagai bahasa asing.

Pemerintah berupaya dengan

berbagai cara untuk mencari solusi karena rendahnya mutu pendidikan, mulai dari perubahan dan pengembangan kurikulum, pengembangan metode pengajaran, melengkapi alat bantu pengajaran, bahkan proses belajar mengajar yang telah dilakukan oleh guru ke arah PBM yang diterima oleh siswa.
Pada saat ini Kurikulum Tingkat Satuan Pendidikan (KTSP), sedang diterapkan sekolahsekolah dengan menggunakan implementasi KTSP ini. Penulis berupaya melakukan PTK tentang reading melalui model pembelajaran Role playing sesuai dengan mata pelajaran yang penulis ampu. Dengan demikian proses pembelajaran yang diteliti akan lebih terarah dan terfokus untuk perbaikanperbaikan pembelajaran berikutnya.

Salah satu faktor yang menyebabkan kurang berhasilnya siswa dalam mengikuti pembelajaran bahasa Inggris adalah siswa kurang minat membaca buku bahasa Inggris atau teks, hal ini disebabkan karena kurang memiliki keterampilan membaca, atau lemahnya keterampilan membaca pemahaman yang disebut dengan reading comprehension atau silent reading. Selain rendahnya minat membaca siswa, aktivitas belajar siswa juga sangat rendah dilihat dari hasil belajar siswa pada nilai akhir semester sebelumnya rata-rata 55. Penulis sangat prihatin dengan permasalahan tersebut, karena itu penulis berupaya mengetahui lebih jauh tentang faktorfaktor yang menyebabkan rendahnya aktivitas belajar dan perolehan nilai siswa dalam reading yang merupakan salah satu unsur pembahasan dalam bahasa Inggris.

Untuk memudahkan dalam penelitian ini, maka penulis telah mengambil sampel kelas IX-6 SMP Negeri 2 Panyabungan dengan jumlah siswa 24 orang dalam penelitian ini. 
Alasan guru menjadikan kelas ini sebagai sampel dalam penelitian ini karena kelas ini memiliki nilai ratarata kelas rendah pada mata pelajaran bahasa Inggris.

Berdasarkan masalah di atas, maka yang menjadi identifikasi masalah dalam meningkatkan aktivitas belajar siswa berdasarkan Model Pembelajaran Role Playing ditetapkan:

a. Siswa kurang minat membaca buku bahasa Inggris atau teks.

b. Rendahnya aktivitas belajar siswa dalam materi pokok Slice The Union

c. Rendahnya hasil belajar siswa pada mata pelajaran Bahasa Inggris.

d. Model pembelajaran yang masih monoton atau konvensional.

e. Interaksi antara siswa dengan guru kurang pada saat proses belajar-mengajar.

Untuk menyelesaikan masalah-masalah yang dihadapi guru dan siswa, maka guru membatasi permasalahan sesuai dengan kemampuan guru antara lain:

a. Menggunakan Model Pembelajaran Role Playing selama kegiatan belajarmengajar.

b. Subjek penelitian adalah siswa kelas IX-6, semester ganjil SMP Negeri 2 Panyabungan Tahun Pembelajaran 2014/2015. c. Materi pokok yang diterapkan selama pengambilan data adalah Slice The Onion Please

d. Kurikulum yang digunakan adalah KTSP

Berdasarkan latar belakang tersebut, dapat dirumuskan masalah sebagai berikut:

a. Apakah terdapat peningkatan aktivitas belajar bahasa Inggris siswa, khususnya materi Slice The Union dengan Penerapan Model Pembelajaran Role Playing Di Kelas IX-6 SMP Negeri 2 Panyabungan Tahun Pelajaran 2014/2015?

b. Apakah terdapat peningkatan hasil belajar bahasa Inggris siswa khususnya materi Slice The Union dengan Penerapan Model Pembelanjaran Role Playing Di Kelas IX-6 SMP Negeri 2 Panyabungan Tahun Pelajaran 2014/2015?

Pemecahan masalah dalam
penelitian ini yaitu dengan menerapkan model pembelajaran Role Playing. Penerapan model pembelajaran ini diharapkan mampu meningkatkan aktivitas belajar yang bermuara pada perbaikan hasil belajar siswa.

Berdasarkan permasalahan di atas, maka penulis menentukan tujuan penelitian ini sebagai berikut :

a. Untuk mengetahui apakah terdapat peningkatan aktivitas belajar bahasa Inggris siswa, 


\begin{tabular}{|c|c|c|}
\hline \multicolumn{2}{|c|}{ khususnya materi } & Slice \\
\hline The & Union & dengan \\
\hline \multicolumn{2}{|c|}{ Penerapan } & Model \\
\hline \multicolumn{2}{|c|}{ Pembelajaran } & Role \\
\hline Playing & Di Kelas & s IX-6 \\
\hline SMP & Negeri & 2 \\
\hline Panyabs & agan & Tahun \\
\hline
\end{tabular}

b. Untuk mengetahui apakah terdapat peningkatkan hasil belajar bahasa Inggris siswa khususnya materi Slice The Union dengan Penerapan Model Pembelajaran Role Playing Di Kelas IX-6 SMP Negeri 2 Panyabungan Tahun Pelajaran 2014/2015.

Manfaat hasil penelitian tindakan kelas ini pada umumnya dan utamanya adalah untuk meningkatkan prestasi belajar siswa melalui peningkatan Proses Belajar Mengajar (PBM). Secara terinci penulis akan mengemukakan manfaat penelitian sebagai berikut :

\section{a. Manfaat bagi Siswa}

Dengan mengikuti model pembelajaran Role Playing siswa akan lebih termotivasi dalam mengikuti pelajaran, meningkatkan efektivitas belajar dengan mencurahkan segala kemampuan yang dimiliki dan menyenangkan serta akan terjalin kerja sama antar sesama teman, dengan baik.

b. Manfaat bagi Guru

Dengan melakukan model pembelajaran Role Playing akan menambah wawasan dan meningkatkan kemampuan pengelolaan kelas dalam menerapkan berbagai strategi dan mengelola kegiatan belajar yang secara efektif dan efisien serta sebagai pengembangan profesi bagi guru bahasa Inggris.

c. Manfaat bagi Sekolah

Dengan melakukan model pembelajaran Role Playing akan memperkaya wawasan bagi para alumni SMP dalam mengembangkan pengetahuannya di masa yang akan datang dan diharapkan menjadi suatu masukan yang dapat dikembangkan menjadi sebuah model pembinaan dalam proses pembelajaran untuk meningkatkan hasil belajar.

\section{METODOLOGI PENELITIAN}

Pengambilan data untuk penelitian ini dilakukan di SMP Negeri 2 Panyabungan dan pelaksanaannya dilakukan pada bulan September sampai dengan Desember 2014. Penelitian ini merupakan penelitian tindakan kelas (Action Researh Classroom) karena penelitian ini bertujuan menganalisis atau memecahkan suatu masalah yang nyata dalam pendidikan. Hal-hal yang perlu dipersiapkan sebelum melakukan penelitian adalah memilih model pembelajaran yang dinilai sesuai dengan materi dan sarana disekolah yang akan disampaikan. Dalam hal ini guru memilih menerapkan model pembelajaran Role Playing yang kemudian membuat rencana pelaksanaan pembelajaran (RPP), lembar kerja siswa (LKS), Instrument 
tes hasil belajar, instrument aktivitas, dan instrument respon siswa.

Subjek yang digunakan dalam penelitian ini adalah seluruh siswa kelas kelas IX-6 SMP Negeri 2 Panyabungan dengan jumlah siswa 24 orang.

Alat pengumpul data dalam penelitian ini adalah tes berbentuk pilihan berganda, observasi, dan angket. Tes hasil belajar ini digunakan untuk mengetahui kemampuan siswa pada tingkat kognitif dan observasi untuk mengetahui aktivitas belajar siswa.

\section{Tes}

Tes digunakan untuk mengetahui hasil belajar siswa sebelum dan sesudah pembelajaran dengan Role Playing. Tes disusun dalam bentuk pilihan ganda yang mengacu pada Kurikulum Tingkat Satuan Pendidikan (KTSP) untuk SMP kelas IX-6 semester I. Tes yang digunakan sebanyak 10 item dengan 4 option.

\section{Tabel 3.1 : Tabel Spesifikasi Materi Pokok Slice The Onion Please}

\begin{tabular}{|c|c|c|c|c|c|c|c|}
\hline \multirow{2}{*}{ Sub Materi } & \multicolumn{6}{|c|}{ Klasifikasi / Kategori } & \multirow{2}{*}{$\begin{array}{l}\text { Jumlah } \\
\text { soal }\end{array}$} \\
\hline & $\mathrm{C}_{1}$ & $\mathrm{C}_{2}$ & $\mathrm{C}_{3}$ & $\mathrm{C}_{4}$ & $\mathrm{C}_{5}$ & $\mathrm{C}_{6}$ & \\
\hline & 1 & 2 & 3 & & & & 2 \\
\hline & & 7 & & 6 & & & 2 \\
\hline & & & 8,9 & 6 & & & 3 \\
\hline & 5 & 4 & & 1 & & & 3 \\
\hline JUMLAH & & & & & & & 10 \\
\hline
\end{tabular}

Keterangan :

$$
\begin{aligned}
& \mathrm{C}_{1}: \text { Pengetahuan } \\
& \mathrm{C}_{2}: \text { Pemahaman } \\
& \mathrm{C}_{3}: \text { Aplikasi } \\
& \mathrm{C}_{4}: \text { Analisis } \\
& \mathrm{C}_{5}: \text { Sintesis } \\
& \mathrm{C}_{6}: \text { Evaluasi }
\end{aligned}
$$

\section{Observasi}

Observasi dalam penelitian ini adalah observasi yang dilakukan untuk mengetahui afektif dan aktivitas siswa selama pembelajaran. Adapun manfaat observasi dalam penelitian ini adalah untuk memperoleh gambaran tentang keseluruhan objek yaitu memperoleh informasi balikan guru di dalam kegiatan belajar mengajar. Observasi yang dilakukan bersifat langsung dan dilakukan oleh 2 orang pengamat yang dilengkapi dengan lembar pedoman observasi afektif dan aktivitas belajar siswa.

Lembar aktivitas ini digunakan pada saat siswa bekerja dalam kelompok. Yang menggunakan lembar aktivitas belajar siswa ini adalah dua orang pengamat, yang mengamati masing-masing satu kelompok setiap satu KBM yang sudah ditentukan oleh guru. Pengamat aktivitas siswa selama KBM diambil sesama guru antara lain Syamsidar Hasibuan, S.Pd dan Rusmi Jambak, S.Pd Pengamat tidak boleh duduk bersamaan untuk menghindari data bias. Pengamat mentabulasi data/menceklis pada lembar aktivitas ini selama dua menit sekali. Akhir kerja kelompok maka pengamat menandatangani lembar pengamat kemudian menyerahkan kepada guru. Sebagai contoh, bila kerja kelompok 
ditentukan oleh guru selama 20 menit maka pengisian data pada lembar aktivitas jumlah per siswa ada 10 ceklis. 10 ceklis ini posisinya pada 5 aktivitas sesuai dengan pengamatan. Setelah data terkumpul, maka data tersebut dianalisis sehingga setiap aktivitas dapat ditentukan persentasinya.

\section{Jenis dan Desain Penelitian}

Penelitian ini berbentuk Penelitian Tindakan Kelas (PTK). Dalam bahasa inggris PTK diartikan dengan Clasroom Action Research, disingkat CAR. PTK pertama kali diperkenalkan oleh psikologi sosial Amerika yang bernama Kurt Lewin pada tahun 1946 (Aqib, 2006 :13). Penelitian tindakan kelas adalah penelitian yang dilakukan oleh guru di kelas dengan penekanan pada penyempurnaan atau peningkatan proses pembelajaran. Menurut Lewin dalam Aqib (2006 : 21) menyatakan bahwa dalam satu siklus terdiri atas empat langkah, yaitu perencanaan (planning), tindakan (acting), observasi (observing) dan refleksi (reflecting).

Adapun prosedur pelaksanaan PTK yang penulis rencanakan dalam menuntaskan hasil belajar tersebut adalah sebagai berikut :

\section{Perencanaan (planning)}

a. Menyusun kegiatan tes

b. Melakukan tes diagnostik yang bertujuan untuk mengetahui kamampuan awal siswa sebelum dan sesudah proses pembelajaran Role Playing dimulai. c. Menganalisis kondisi yang bertujuan untuk mengetahui tersedianya alat dan bahan pembelajaran

d. Mengidentifikasi permasalahan yang akan dianalisis berdasarkan tes awal dan analisis kondisi

e. Menyusun Rencana Pelaksanaan Pembelajaran (RPP)

f. Membuat lembar observasi yang bertujuan untuk melihat bagaimana aktivitas balajar siswa selama proses belajar mengajar berlangsung

g. Membuat lembar angket yang bertujuan untuk mengetahui pendapat siswa tentang Role Playing.

\section{Tindakan (acting)}

a) Penyampaian materi pelajaran yang melibatkan aktivitas siswa secara individual maupun kelompok melalui penerapan model Role Playing.

b) Melakukan observasi di dalam kelas yang dilakukan dengan penyediaan format evaluasi. Hal yang menjadi perhatian pengamat adalah aktivitas belajar siswa.

c) Melakukan evaluasi belajar berupa tes, pemberian tugas ataupun kelompok atau individu.

d) Menganalisis evaluasi belajar dari perolehan tes pilihan ganda untuk melihat tingkat keberhasilan siswa yang 
diperoleh melalui penerapan model Role Playing.

e) Observasi (observing)

Tahap ini dilakukan oleh 2 orang pengamat untuk mengamati aktivitas belajar siswa di dalam kelas saat proses pembelajaran berlangsung. Pangamat dilengkapi dengan lembar pedoman observasi yang berfungsi untuk menyaring data yang dibutuhkan berkaitan dengan tindakan penelitian.

f) Refleksi (reflecting)

Refleksi adalah untuk melihat apa yang telah dihasilkan atau yang belum berhasil diselesaikan dengan tidakan perbaikan yang telah dilakukan. Hasil yang ditemukan dalam tahap observasi dianalisis, sehingga memberikan hasil yang bermakna dari data yang diperoleh untuk diambil kesimpulan sebagai tindakan penelitian. Hasil refleksi ini digunakan sebagai dasar untuk tahap perencanaan pada siklus selanjutnya, sehingga hasil belajar siswa meningkat.

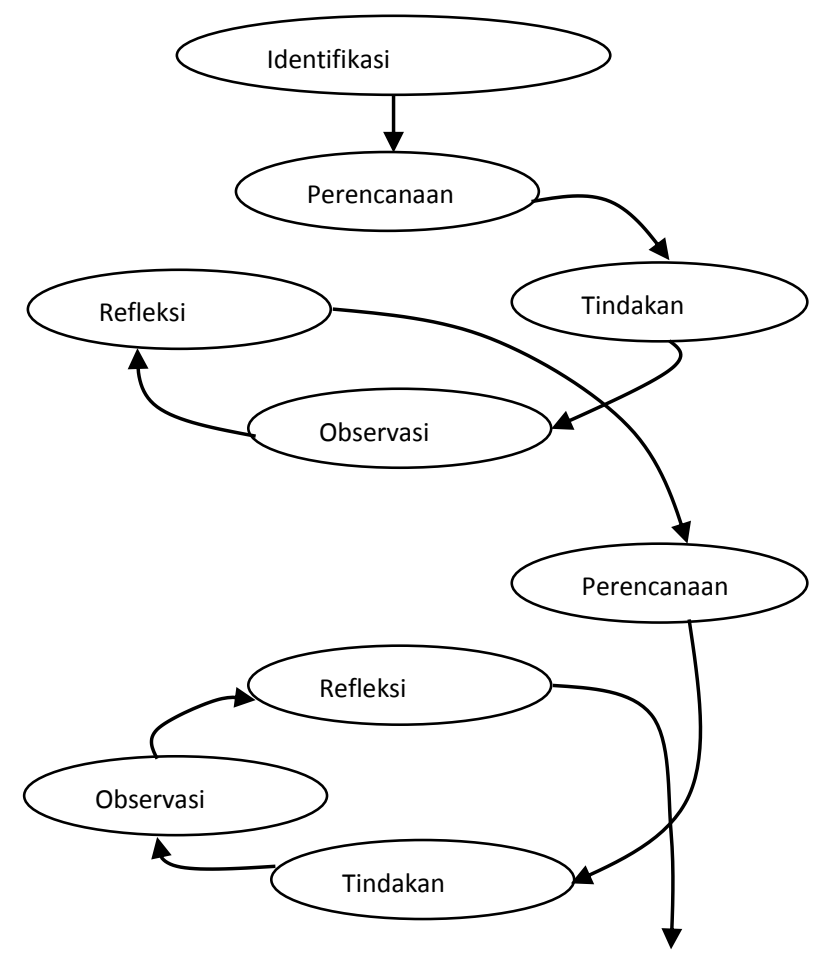

Gambar 3.1 : Spiral Tindakan Kelas

(Hopkins dalam Aqib, 2006 : 31)

\section{Teknik Analisis Data}

Metode Analisis Data Pada penelitian ini digunakan metode deskriptif dengan membandingkan hasil belajar siswa sebelum tindakan dengan hasil belajar siswa setelah tindakan.

Langkah-langkah pengolahan data sebagai berikut:

1. Merekapitulasi nilai pretes sebelum tindakan dan nilai tes akhir siklus I dan siklus II.

2. Menghitung nilai rerata atau persentase hasil belajar siswa sebelum dilakukan tindakan dengan hasil belajar setelah dilakukan tindakan pada siklus I dan siklus II untuk mengetahui adanya peningkatan hasil belajar. 
3. Penilaian

a. Data nilai hasil belajar (kognitif) diperoleh dengan menggunakan rumus:

Nilai Siswa $=\frac{\text { Jumlah jawaban benar }}{\text { Jumlah seluruh soal }} \times 100$

b. Nilai rata-rata siswa dicari dengan rumus sebagai berikut:

$$
\bar{X}=\frac{\sum X}{N}
$$

(Subino, 1987:80)

Keterangan :

$$
\begin{aligned}
& \bar{X}=\text { Nilai rata-rata } \\
& \Sigma=\text { Jumlah nilai } X \\
& \mathrm{~N}=\text { Jumlah peserta tes }
\end{aligned}
$$

a. Untuk penilaian aktivitas digunakan rumus sebagai berikut: $\%$ Proporsi Aktivitas $=$ $\frac{\text { jumlah skor yang diperoleh }}{\text { jumlah skor ideal }} \times 100 \%$

(Majid, 2009:268)

b. Ketentuan persentase ketuntasan belajar kelas Ketuntasan belajar kelas $=\frac{\sum S_{b}}{K} \times 100 \%$ $\Sigma \mathrm{Sb}=$ Jumlah siswa yang mendapat nilai $\geq 65 \quad$ (kognitif) $\Sigma \mathrm{K}=$ Jumlah siswa dalam sampel

Sebagai tolak ukur keberhasilan penelitian tindakan kelas ini dapat dilihat dari hasil tes, jika hasil belajar siswa mencapai KKM secara individual dan $85 \%$ secara klasikal.

\section{HASIL PENELITIAN DAN PEMBAHASAN}

Dari hasil pengamatan didalam kelas, peneliti memperhatikan adanya perbedanya hasil belajar siswa kelas IX-6 dengan siswa kelas IX lainnya. Hal ini ditunjukkan dari banyaknya siswa kelas IX-6 yang belum mencapai standar Kriteria Ketuntasan Minimal (KKM) yang telah ditetapkan oleh pihak sekolah, yaitu 65 untuk mata pelajaran Bahasa Inggris. Pada saat diadakan ulangan harian, kelas IX-6 selalu memiliki nilai rata-rata paling rendah bila dibanding kelas IX yang lain.

Berikut ini akan dijelaskan kondisi awal siswa kelas IX-6 yang menyangkut hasil belajar siswa pada mata pelajaran Bahasa Inggris. Untuk mempertegas identifikasi tersebut dilakukan pretest terhadap kelas IX-6. Namun hasil dari pretest terlihat bahwa rata-rata nilai siswa masih sangat rendah yaitu 47,9 sedangkan KKM

Bahasa Inggris adalah 65 dengan nilai tertinggi 80 dan nilai terendah yaitu 20. Oleh sebab itu maka dilanjutkanlah tindakan pada siklus I.

\section{Data Siklus I}

Dengan mengingat penelitian tindakan kelas harus dilakukan secara alami, maka pelaksanaan siklus I direncanakan bersamaan dengan mulainya materi "Slice The Onion Please", sehingga kegiatan penelitian terintegrasi dengan Kegiatan 
Pembelajaran sebagaimana pelajaran yang telah berlangsung selama ini.

\section{Perencanaan.}

Pada tahap ini guru mempersiapkan perangkat pembelajaran yang terdiri dari RPP 1 dan 2, LKS 1 dan 2, soal tes formatif 1, dan alat-alat pengajaran dan media untuk mendukung kegiatan belajar mengajar. Sebelum pelaksanaan KBM, guru menginformasikan metode pembelajaran Role Playing ini kepada siswa sehingga pada saat pelaksanaan siswa sudah memahami.

a.

Oleh karena pada skenario ini membutuhkan permaian pemeran, maka guru menunjuk dua orang siswa yang guru anggap cukup mampu untuk memerankan peran yang telah direncanakan dalam skenario tersebut. Dua hari sebelum pelaksanaan siklus I skenario pembelajaran diserahkan kepada siswa yang bertugas sebagai tokoh pemeran untuk dipelajari. Selanjutnya guru membagi siswa dalam kelompokkelompok. Masing-masing kelompok terdiri atas 4 siswa. Pembentukan kelompok ini didasarkan atas jumlah siswa dalam satu kelas, pemerataan kemampuan siswa serta pemerataan jenis kelamin siswa. Karena jumlah siswa dalam satu kelas ada 24 siswa maka pembagian kelompok bisa merata dengan jumlah 6 kelompok.

\section{Pelaksanaan}

KBM 1

KBM 1 dilaksanakan pada hari Kamis, 23 Oktober 2014 les ke 1 sampai dengan les 2 Sebelum pelajaran dimulai guru minta kepada setiap anggota kelompok menempati dan bergabung dengan kelompok masing-masing. Selanjutnya guru mulai membuka pelajaran dengan menuliskan Kompetensi Dasar yang akan dipelajari serta menekankan tentang tujuan pembelajaran. Langkah berikutnya, guru memberikan pertanyaan awal sebagai pra pengetahuan siswa tentang Scrip dialog tentang asking and giving certainty dan menunjuk salah seorang anggota kelompok 1 yang bernama Ahmad untuk menuliskan jawaban di papan tulis.

Tahap berikutnya guru mempersilahkan siswa yang bertugas memerankan skenario untuk maju kedepan kelas dan melaksanakan tugasnya, sementara itu setiap kelompok mengamati dengan seksama. Agar lebih jelas, pemeran diminta untuk mengulangi adegan sekali lagi.

Setelah memerankan tugasnya siswa diminta bergabung dengan kelompoknya untuk berdiskusi dan mengerjakan LKS (Lembar Kerja Siswa) yang telah dibagikan. Dari hasil diskusi, setiap kelompok yang diwakili salah satu anggotanya secara bergilir menyampaikan hasil diskusinya, kemudian guru melakukan validasi hasil kesimpulan siswa serta mempersilahkan siswa kembali ke tempat duduk masing-masing untuk mengerjakan soal evaluasi.

\section{KBM 2}

\section{Kamis, 30 Oktober 2014 les ke 1 sampai} dengan les ke 2 Sebelum pelajaran dimulai guru minta kepada setiap anggota kelompok menempati dan bergabung dengan kelompok masing-masing. Selanjutnya guru mulai membuka pelajaran dengan menuliskan Kompetensi Dasar yang akan dipelajari serta menekankan tentang tujuan pembelajaran.

$$
\text { Langkah berikutnya, guru }
$$
memberikan pertanyaan awal sebagai pra pengetahuan siswa tentang Scrip dialog yg menggunakan expressing and renponding to 
dubt dan menunjuk salah seorang anggota kelompok 3 yang bernama Choirul untuk menuliskan jawaban di papan tulis.

Tahap berikutnya guru mempersilahkan siswa yang bertugas memerankan skenario untuk maju kedepan kelas dan melaksanakan tugasnya, sementara itu setiap kelompok mengamati dengan seksama. Agar lebih jelas, pemeran diminta untuk mengulangi adegan sekali lagi.

Setelah memerankan tugasnya siswa diminta bergabung dengan kelompoknya untuk berdiskusi dan mengerjakan LKS (Lembar Kerja Siswa) yang telah dibagikan., Kemudian guru melakukan validasi hasil kesimpulan siswa serta mempersilahkan siswa kembali ke tempat duduk masing-masing untuk mengerjakan soal evaluasi.

\section{Observasi}

Data Hasil Belajar Siklus 1

Awalnya guru mengadakan pretest terlebih dahulu, namun yang diperoleh bahwa data pretes mengisyaratkan siswa tidak mempersiapkan diri belajar dirumah sebelum mempelajari materi baru yang akan disampaikan guru di sekolah sekaligus dapat disimpulkan bahwa motivasi dan kemandirian belajar siswa sangat rendah. Sehingga guru berdiskusi bersama pembimbing dan pendamping penelitian untuk merumuskan perencanaan pembelajaran siklus I.

Setelah berakhirnya pelaksanaan siklus I diadakan tes hasil belajar kognitif yang selanjutnya disebut sebagai Formatif I. Hasil belajar kognitif yang diperoleh pada siklus I selama dua pertemuan disajikan dalam Tabel 4.1
Tabel 4.1 Distribusi Hasil Formatif I

\begin{tabular}{|c|c|c|c|c|}
\hline Nilai & Frekunsi & $\begin{array}{c}\text { Tuntas } \\
\text { Individu }\end{array}$ & $\begin{array}{c}\text { Tuntas } \\
\text { Kelas }\end{array}$ & Rata-rata \\
\hline 40 & 7 & - & - & \multirow{5}{*}{64,2} \\
\hline 60 & 7 & - & - & \\
\hline 80 & 8 & 8 & $33,33 \%$ & \\
\hline 100 & 2 & 2 & $8,33 \%$ & \\
\hline Jumlah & 24 & 10 & $41,67 \%$ & \\
\hline
\end{tabular}

Dari tabel 4.1 diatas dapat dilihat bahwa hanya ada 10 orang saja yang dapat memenuhi nilai KKM mencapai nilai 65, sedangkan 12 orang lagi dinyatakan tidak tuntas dengan nilai ketuntasan klasikal sebesar 41,67\%.

Data hasil Formatif I ini dapat disajikan dalam grafik histogram seperti pada Gambar 4.1.

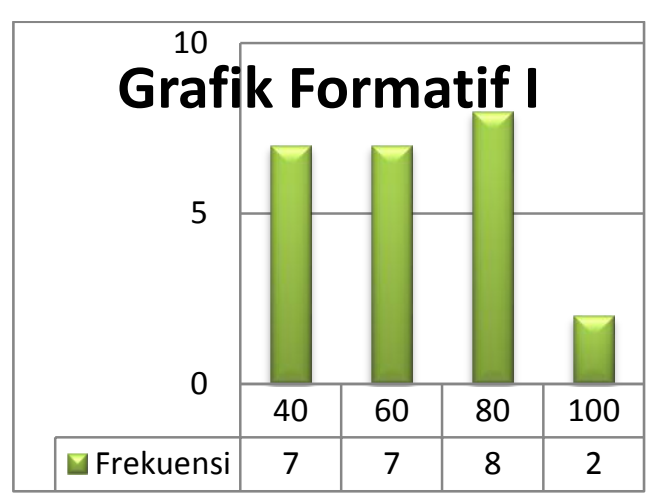

\section{Gambar .4.1 Grafik Data Hasil Formatif I}

\section{Data Aktivitas Siklus 1}

Data aktivitas siklus 1 yang kemudian diperoleh dari 2 orang pengamat yang bertugas sebagai observer tersaji seperti dalam table 4.2. Tabel 4.2 Skor aktivitas belajar diperoleh dari lembar observasi aktivitas. 
Adapun data aktivitas yang diperoleh pada Siklus I adalah seabagai berikut.

\section{Tabel 4.2 Skor Aktivitas Belajar}

Siswa

\begin{tabular}{|c|l|c|c|}
\hline \multicolumn{4}{|c|}{ Siklus I } \\
\hline No & Aktivitas & Rata-Rata & Proporsi \\
\hline 1 & Menulis,membaca & 15 & $38 \%$ \\
\hline 2 & Mengerjakan & 13 & $31 \%$ \\
\hline 3 & $\begin{array}{l}\text { Bertanya pada } \\
\text { teman }\end{array}$ & 9 & $21 \%$ \\
\hline 4 & Bertanya pada guru & 2 & $5 \%$ \\
\hline 5 & Yang tidak relevan & 2 & $5 \%$ \\
\hline \multicolumn{2}{|c|}{ Jumlah } & 40 & $100 \%$ \\
\hline
\end{tabular}

Dari tabel aktivitas diatas tampak jumlah siswa yang menulis dan membaca lebih banyak dari jumlah siswa dalam melakukan kegiatan lainnya, yang berarti siswa cenderung pasif didalam kelompok. Untuk lebih jelas, aktivitas siswa tampak dalam grafik dibawah.

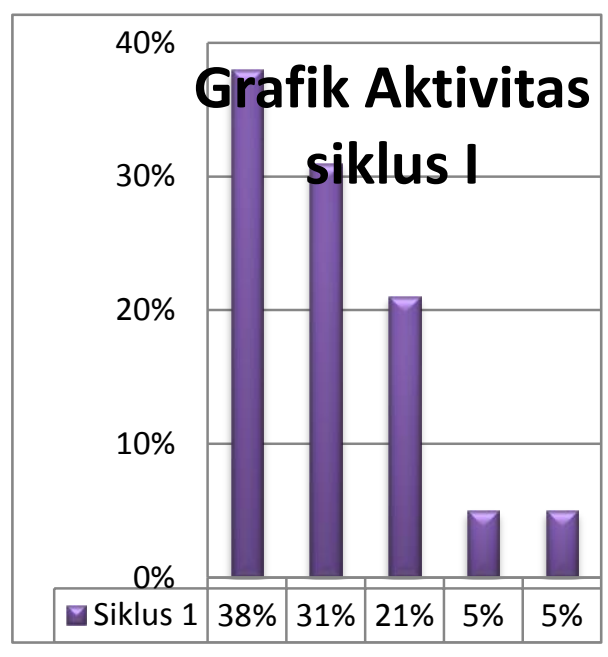

\section{Gambar 4.2. Grafik aktivitas siswa Siklus I}

Keterangan: 1. Menulis,membaca

2. Mengerjakan

3. Bertanya pada teman

4. Bertanya pada guru

5. Yang tidak relevan

\section{a. Refleksi siklus I}

Berdasarkan data Tabel 4.1 diperoleh bahwa rata-rata Formatif 64,2 pada Siklus I dengan persentase adalah $41,67 \%$. Nilai ini menggambarkan bahwa ketuntasan belajar belum tercapai karena rata-rata nilai yang diperoleh kelas belum mencapai nilai ketuntasan klasikal yang ditetapkan, yaitu $85 \%$.

Belum tercapainya standar ketuntasan tersebut tidak terlepas dari rendahnya aktivitas belajar siswa. Merujuk pada Tabel 4.2, pada Siklus I rata-rata aktivitas I yakni menulis dan membaca memperoleh proporsi $38 \%$. Aktivitas mengerjakan dalam diskusi mencapai 31\%. Aktivitas bertanya pada teman sebesar $21 \%$. Aktivitas bertanya kepada guru 5\% dan aktivitas yang tidak relevan dengan KBM sebesar 5\%. Hal ini disebabkan beberapa hal yaitu:

a) Siswa kelihatan kurang nyaman dengan hadirnya kolaborator (pengamat), ini dapat diamati dari tingkah laku siswa yang setiap saat menoleh kebelakang untuk melihat kolaborator.

b) Ada kelompok yang kurang berani maju untuk mempresentasikan hasil diskusinya, hal ini dapat diamati dari anggota kelompok yang saling menunjuk temannya ketika mendapat giliran untuk maju.

c) Ada beberapa anggota kelompok yang masih kurang aktif dalam kegiatan diskusi sehingga hanya didominasi oleh sebagian anggota yang 
lain, sementara itu ada kelompok yang hampir semua anggotanya sangat aktif.

\section{b. Tindakan}

\section{Pembelajaran Siklus I}

Hasil belajar siklus I belum dapat dikatakan berarti menilik KKM yang ada. Sehingga guru harus mempersiapkan untuk mengidentifikasi dan memperbaiki permasalahan untuk menerapkan siklus berikutnya. Memberikan motivasi kepada siswa dengan menginformasikan semua nilai-nilai yang diperoleh siswa selama Siklus I, serta cara-cara belajar yang efektif. Perbaikan-perbaikan pembelajaran ini akan diterapkan pada Siklus II antara lain:

a) Siswa merasa kurang nyaman ketika kolaborator berada dalam ruangan, untuk itu pada pembelajaran berikutnya perlu dijelaskan pada siswa bahwa kedudukan kolaborator hanya terbatas sebagai pengamat saja tanpa ada kaitan dengan tingkah laku siswa maupun penilaian.

b) Adanya kelompok yang cukup aktif, tetapi ada juga yang pasif. Untuk itu melalui diskusi antara guru dan pengamat pada siklus berikutnya perlu diadakan perubahan posisi kelompok sehingga keaktifan kelompok merata. Sedangkan adanya anggota kelompok yang kurang aktif memang perlu diberi motivasi khusus, misalnya dengan memberi pertanyaan individu yang harus dijawab oleh siswa tersebut.

c) Mengingat pemeran skenario kurang semangat/agak kaku dalam memainkan peranannya maka pada siklus berikutnya perlu diadakan pergantian pemain.

\section{Data Siklus II}

\section{a. Perencanaan}

Pada siklus kedua ini guru memulai dengan pembuatan skenario pembelajaran. Seperti halnya pada siklus I, skenario yang pada dasarnya menjelaskan tentang Slice the onion, please. , sudah harus diserahkan kepada siswa yang akan bertugas sebagai pemeran pada pertemuan sebelum pelaksanaan kegiatan pembelajaran siklus kedua. Siswa yang ditugasi untuk memerankan dalam skenario silus kedua dipilihkan dari siswa lain yang bukan pemeran pada siklus I yang guru anggap lebih mampu.

Berdasarkan temuan yang ada pada siklus I guru mencoba untuk mengubah posisi kelompok dengan membagi rata siswa yang kelihatan aktif pada pelaksanaan pembelajaran di siklus I. Tentang ketidaknyamanan siswa dengan adanya kolaborator, maka guru mencoba untuk menjelaskan pada siswa bahwa kedudukan kolaborator hanya terbatas sebagai pengamat tanpa mempengaruhi nilai siswa baik kognitif maupun afektif. 


\section{b. Pelaksanaan}

\section{KBM 3}

KBM 3 dilaksanakan pada hari Kamis, 6 Nopember 2014 tepatnya pada les ke 1 sampai dengan 2. Berdasarkan temuantemuan yang ada pada siklus I, maka pelaksanaan kegiatan siklus II mengulangi kegiatan yang ada pada siklus I setelah mengalami perbaikan-perbaikan ataupun revisi. Seperti halnya pada siklus I, pada tahap awal yang dilakukan oleh guru adalah menuliskan kompetensi dasar dan tujuan pembelajaran.

Untuk menggali kemampuan awal siswa sebelum memasuki materi Scrip dialog yg berisi expressing and ashingfor cetainty, maka guru memberikan pertanyaan sebagai pra pengetahuan.

Kali ini yang ditunjuk adalah siswa yang dianggap guru tidak aktif pada saat kegiatan siklus I yaitu siswa dari kelompok 5 yang bernama Anggi. Meskipun jawaban yang diberikan salah, guru tetap memberikan penghargaan atas keberaniannya dalam menjawab.

Setelah pemeran menyelesaikan tugasnya, setiap kelompok berdiskusi untuk membahas apa yang telah dilakukan oleh pemeran sekaligus mengerjakan LKS yang sudah dibagikan

Sementara siswa berdiskusi, guru mencoba berjalan berkeliling ke masingmasing kelompok untuk memberi motivasi, kemudian mempersilahkan kelompok yang sudah selesai untuk lebih dulu mempresentasikan hasil diskusinya. Setelah semua kelompok menyelesaikan tugasnya guru memvalidasi hasil / kesimpulan.

\section{KBM 4}

KBM 4 dilaksanakan pada hari Kamis, 13 Nopember 2014 tepatnya pada les ke 1 sampai dengan 2. Berdasarkan temuantemuan yang ada pada siklus I, maka pelaksanaan kegiatan siklus II mengulangi kegiatan yang ada pada siklus I setelah mengalami perbaikan-perbaikan ataupun revisi. Seperti halnya pada siklus I, pada tahap awal yang dilakukan oleh guru adalah menuliskan kompetensi dasar dan tujuan pembelajaran.
Untuk menggali kemampuan awal siswa sebelum memasuki materi Scrip dialog yg menggunakan expressing and renponding to $d u b t$, maka guru memberikan pertanyaan sebagai pra pengetahuan.

Meskipun jawaban yang diberikan salah, guru tetap memberikan penghargaan atas keberaniannya dalam menjawab. Hal ini guru anggap sebagai salah satu upaya untuk memotivasi siswa agar berperan aktif dalam proses belajar-mengajar.

Tahap berikutnya siswa kembali diminta bergabung dengan kelompok masingmasing yang telah mengalami perubahan posisi, setiap kelompok berdiskusi untuk membahas apa yang telah dilakukan oleh pemeran sekaligus mengerjakan LKS yang sudah dibagikan

Sementara siswa berdiskusi, guru mencoba berjalan berkeliling ke masingmasing kelompok untuk memberi motivasi, kemudian mempersilahkan kelompok yang sudah selesai untuk lebih dulu mempresentasikan hasil diskusinya. Setelah semua kelompok menyelesaikan tugasnya guru memvalidasi hasil/kesimpulan. Selanjutnya guru melakukan tes formatif II 15 menit sebelum meninggalkan kelas. Tahap akhir dari kegiatan pelaksanaan siklus II adalah menutup kegiatan pembelajaran dengan mengucapkan 'Assalamualikum dan selamat pagi" serentak siswa menjawab “walaikum salam! Pagi Bu!".

\section{c. Observasi \\ Data Hasil Belajar Siklus 2}

Setelah menetapkan beberapa tindakan perbaikan pembelajaran yang akan dilakukan pada siklus II maka disusun perangkat-perangkat pembelajaran untuk siklus II. Setelah siklus II dilakukan, diakhir siklus II diberikan tes hasil belajar sebagai Formatif II. Data Formatif II disajikankan dalam Tabel 4.3

\section{Tabel 4.3. Distribusi Hasil Formatif}

\section{II}




\begin{tabular}{|c|c|c|c|c|}
\hline Nilai & frekuensi & $\begin{array}{c}\text { Tuntas } \\
\text { Individu }\end{array}$ & $\begin{array}{c}\text { Tuntas } \\
\text { Kelas }\end{array}$ & $\begin{array}{c}\text { Nilai } \\
\text { rata-rata }\end{array}$ \\
\hline 40 & 1 & - & - & \\
\cline { 1 - 4 } & 2 & - & - & \multirow{2}{*}{80,83} \\
\cline { 1 - 4 } 80 & 16 & 16 & $66,66 \%$ & \\
\cline { 1 - 4 } 100 & 5 & 5 & $20,83 \%$ & \\
\cline { 1 - 4 } Jumlah & 24 & 21 & $87,49 \%$ & \\
\hline
\end{tabular}

Data hasil potes II ini dapat disajikan dalam grafik histogram, grafiknya dapat dilihat pada Gambar 4.3.

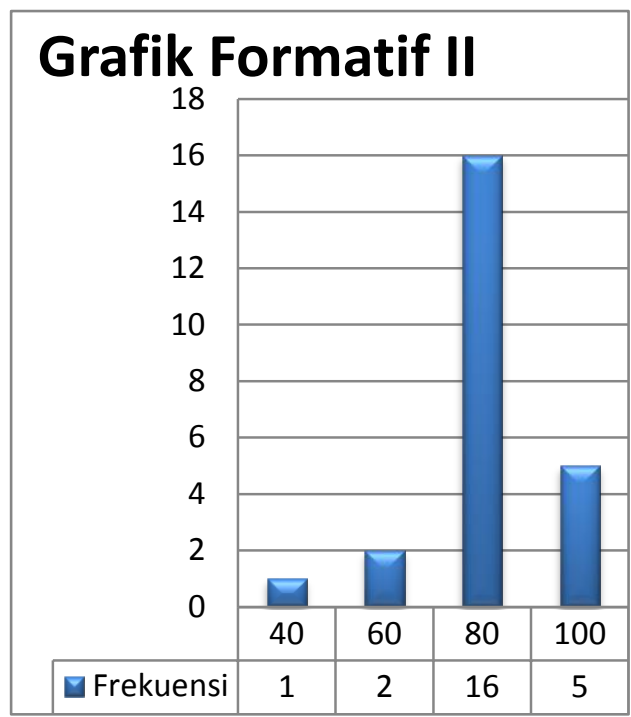

Gambar 4.3 Grafik Data Hasil Formatif II

Data yang telah diuraikan diatas menunjukkan bahwa terjadi peningkatan hasil belajar siswa mulai dari Pretes ke Formatif I sampai ke Formatif II. Namun Formatif I menunjukkan bahwa pembelajaran Siklus I belum mampu meningkatakan hasil belajar siswa sampai pada ketuntasan klasikal yang diharapkan. Ketuntasan klasikal baru dapat diperoleh pada Siklus II ditunjukkan pada Siklus II, dengan masih meninggalkan 3 orang siswa belum tuntas hasil belajarnya. Setelah berlangsungnya Siklus II, guru melakukan tes akhir Siklus II yakni Formatif II dengan perolehan nilai rata-rata 80,83 dan ketuntasan klasikal 87,49\%. Dengan demikian hasil Formatif II menyatakan bahwa pembelajaran Siklus II telah berhasil meningkatkan hasil belajar siswa dan memberikan ketuntasan baik rata-rata maupun secara klasikal.

\section{Data aktivitas Siklus II}

Penilaian aktivitas diperoleh dari lembar observasi aktivitas. Pengamatan dilakukan oleh dua pengamat selama 20 menit kerja kelompok dalam setiap KBM atau 40 menit dalam satu Siklus. Dengan pengamatan setiap 2 menit, maka nilai maksimum yang mungkin teramati untuk satu kategori aktivitas selama 40 menit adalah 20 kali sama seperti pada siklus I. Pada Siklus II aktivitas menulis dan membaca turun menjadi $30 \%$, kondisi ini mengalami kenaikan aktivitas mengerjakan dalam diskusi yang meningkat cukup tajam menjadi $38 \%$. Sementara aktivitas bertanya pada teman naik menjadi $23 \%$ dan bertanya pada guru naik menjadi $7 \%$. Kesimpulan ini diperkuat dengan temuan bahwa aktivitas yang tidak relevan dengan KBM pada Siklus II menyusut mencapai 3\%. Data aktivitas belajar siswa secaraa lengkap disajikan dalam Tabel 4.5 berikut:

Tabel 4.4 Skor aktivitas belajar siswa

\begin{tabular}{|l|l|l|l|}
\hline \multicolumn{5}{|c|}{ Siklus II } \\
\hline No & Aktivitas & Rata-Rata & Proporsi \\
\hline
\end{tabular}




\begin{tabular}{|l|l|c|c|}
1 & Menulis,membaca & 12 & $30 \%$ \\
\hline 2 & Mengerjakan & 15 & $38 \%$ \\
\hline 3 & Bertanya pada teman & 9 & $23 \%$ \\
\hline 4 & Bertanya pada guru & 3 & $7 \%$ \\
\hline 5 & Yang tidak relevan & 1 & $3 \%$ \\
\hline \multicolumn{2}{|l|}{ Rata-rata proporsi } & $100 \%$ \\
\hline
\end{tabular}

Gambar 4.4. Grafik Aktivitas Siklus II

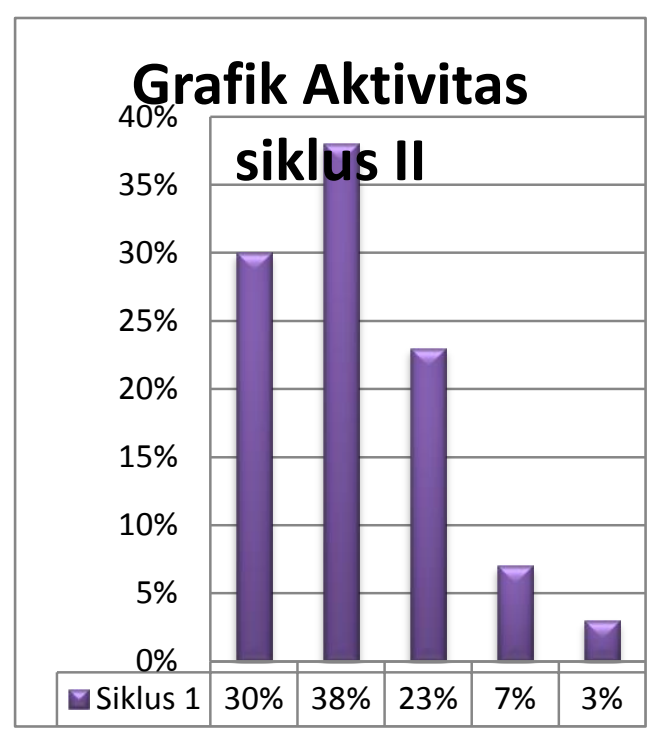

Pada data diatas terlihat bahwa aktivitas siswa menulis dan membaca menurun dan berubah meningkat pada aktivitas mengerjakan. Dapat dikatakan bahwa siswa semakin aktif didalam kelompoknya.

\section{Pembahasan}

Saat melakukan pembelajaran, terlebih dahulu guru mengadakan pretest untuk mengetahui kemampuan awal siswa sehingga dapat dibandingkan dengan kemampuan siswa sesudah menggunakan model pembelajaran. Nilai rata-rata pretes 47,9 dengan KKM (kriteria ketuntasan minimum) sebesar 65 maka hanya ada dua orang siswa mencapai nilai diatas ketuntasan atau ketuntasan klasikal adalah $8,3 \%$. Dari data tersebut dapat disimpulkan bahwa siswa tidak mempersiapkan diri dengan belajar dirumah sebelum datang ke sekolah.

Perencanaan

untuk

melaksanakan tindakan pada Siklus I adalah berdasarkan hasil diskusi bersama pembimbing penelitian, diawali dengan membagi kelompokkelompok diskusi sesuai dengan model pembelajaran Role Playing. Dari jumlah keseluruhan siswa dalam kelas IX-6 yaitu 24 siswa akan dibagi menjadi 6 kelompok belajar dan masing-masing kelompok terdiri dari 4 siswa yang heterogen. Pembagian kelompok didasarkan pada nilai pretes sehingga pembentukan kelompok memenuhi kriteria heterogen dalam kemampuan awal. Pada tahap perencanaan penulis mempersiapkan beberapa komponen terkait dengan materi garis dan sudut yang akan disampaikan. Hal-hal yang direncanakan pada Siklus I antara lain:

a. Menyiapkan silabus berdasarkan kurikulum yang digunakan (lampiran).

b. Membuat Rencana Pelaksanaan pembelajaran (RPP) tentang materi yang akan diajarkan dengan menggunakan model pembelajaran Role Playing.

c. Menyiapkan LKS

d. Menyiapkan media berupa Role Playing dari karton yang akan digunakan dalam proses pembelajaran.

e. Menyusun dan menyiapkan angket dan lembar observasi 
untuk mengukur minat siswa dan aktivitas siswa terhadap pelajaran Bahasa Inggris (lampiran)

f. Membagi kisi-kisi tes hasil belajar siswa yang digunakan pada pretes menjadi dua bagian dengan indikator yang dipelajari pada siklus I sebagai Formatif I dan indikator pada siklus II sebagai Formatif II.

Siklus I dilaksanakan dalam dua kali pertemuan. Proses pembelajaran dilakukan sesuai RPP yang telah disusun untuk siklus I. Pada pelaksanaan pembelajaran siklus I ini Peneliti sebagai guru dibantu dua guru sejawat yang bertindak sebagai observer yang membantu guru mengamati aktivitas belajar siswa. Setelah berakhirnya siklus I dilaksanakan Formatif I.

Nilai terendah Formatif I adalah 40 dan tertinggi adalah 100. Merujuk pada KKM sebesar 65 maka 10 dari 24 orang siswa mendapat nilai dibawah kriteria ketuntasan atau ketuntasan klasikal adalah sebesar $41,67 \%$. Nilai ini berada di bawah kriteria ketuntasan klasikal sebesar $85 \%$ sehingga dapat dikatakan KBM siklus I tidak berhasil memberi ketuntasan belajar dalam kelas. Nilai rata-rata kelas adalah 64,2 yang juga di bawah KKM.

Berdasarkan kekurangankekurangan yang ada pada Siklus I tersebut, maka diperlukan adanya perbaikan pada siklus II. Perbaikan yang akan dilakukan didiskusikan guru bersama guru sejawat, pembimbing dan pendamping. Setelah dilakukan diskusi dihasilkan beberapa tindaka yang sebaiknya dilakukan. Hal-hal yang dilakukan perbaikan antara lain:

a. Siswa merasa kurang nyaman ketika kolaborator berada dalam ruangan, untuk itu pada pembelajaran berikutnya perlu dijelaskan pada siswa bahwa kedudukan kolaborator hanya terbatas sebagai pengamat saja tanpa ada kaitan dengan tingkah laku siswa maupun penilaian.

b. Adanya kelompok yang cukup aktif, tetapi ada juga yang pasif. Untuk itu melalui diskusi antara guru dan pengamat pada siklus berikutnya perlu diadakan perubahan posisi kelompok sehingga keaktifan kelompok merata. Sedangkan adanya anggota kelompok yang kurang aktif memang perlu diberi motivasi khusus, misalnya dengan memberi pertanyaan individu yang harus dijawab oleh siswa tersebut.

c. Mengingat pemeran skenario kurang semangat / agak kaku dalam memainkan peranannya maka pada siklus berikutnya perlu diadakan pergantian pemain.

Di akhir pembelajaran siklus II dilakukan Formatif II. Nilai terendah untuk Formatif II adalah 60 dan tertinggi adalah 100 dengan 3 dari 24 orang mendapat nilai dibawah KKM atau ketuntasan klasikal adalah sebesar $87,50 \%$. Nilai ini telah berada di atas kriteria keberhasilan sehingga dapat dikatakan KBM siklus II telah berhasil memberi ketuntasan belajar pada 
siswa dalam kelas. Nilai rata-rata kelas adalah 80,83 telah memenuhi KKM. Hal ini sesuai dengan pendapat Mulyasa. E (2000:99), yang menyatakan bahwa pengajaran dikatakan tuntas jika telah memenuhi ketuntasan belajar lebih dari $85 \%$.

Hasil belajar siswa diakhir siklus II telah mencapai ketuntasan klasikal 87,50\%, yang berarti 21 dari 24 siswa telah memperoleh nilai tuntas. Dengan demikian tindakan yang diberikan pada siklus II telah berhasil memberikan perbaikan hasil belajar pada siswa. Pada pembelajaran siklus II Role Playing yang divariasi dengan berkelompok dan mencari pasangan kartu serta adu cepat menempelkan kartu, membuat mereka tidak lagi merasa bosan bahkan sebaliknya mereka merasa bahwa belajar Bahasa Inggris itu menyenangkan. Terbukti dengan dokumentasi yang menunjukkan raut muka yang ceria dan semangat yang cukup bagus dari siswa ketika diterapkan model Role Playing didukung dengan komentar siswa ketika ditanya oleh guru tentang respon siswa terhadap model Role Playing yang baru dilaksanakan.

\section{SIMPULAN DAN SARAN}

\section{Simpulan}

Data-data tes hasil belajar dan aktivitas belajar siswa selama kegiatan belajar mengajar tersusun, kemudian dianalisis, sehingga dapat disimpulkan sesuai dengan rumusan masalah. a. Data aktivitas siswa menurut kedua pengamatan pengamat pada Siklus I antara lain: menulis/membaca (38\%), bekerja $(31 \%)$ ), bertanya sesama teman (21\%), bertanya kepada guru (5\%), dan yang tidak relevan dengan KBM (5\%). Data aktivitas siswa menurut pengamatan pada Siklus II antara lain: menulis/membaca (30\%), bekerja (38\%), bertanya sesama teman (23\%), bertanya kepada guru (7\%), dan yang tidak relevan dengan KBM (3\%).

b. Dengan menggunakan model pembelajaran Role Playing. hasil belajar Bahasa Inggris siswa dari Siklus ke Siklus berikutnya mengalami peningkatan. Hasil belajar siswa dengan menerapkan model pembelajaran Role Playing pada Formatif I menunjukkan 10 orang siswa tuntas secara individu, sedangkan kelas 41,67\% . Pada Siklus II, tuntas secara individu sebanyak 21 orang siswa, sedangkan persentase ketuntasan klasikal yaitu $87,50 \%$. Dengan nilai rata-rata pada siklus I adalah 64,2 dan pada siklus II adalah 80,83 .

\section{Saran}

Setelah melakukan kegiatan belajar mengajar selama empat kali (Siklus I, II) maka diperoleh data-data kemudian data tersebut di analisis dan juga hasil rekaman guru selama KBM maka perlu saran agar pengguna atau model pembelajaran Role Playing 
Selama Kegiatan Belajar di sekolah benar-benar bermanfaat sesuai dengan tujuan penelitian.

a. Melalui penerapan model pembelajaran Role Playing masih ada beberapa aspek aktivitas belajar yang perlu ditingkatkan, yaitu bertanya kepada guru, dan masih adanya beberapa siswa yang melakukan aktivitas belajar yang tidak relevan dengan kompetensi yang akan dicapai. Atas dasar ini, disarankan bagi guru lanjut agar melakukan penelitian yang sejenis dengan lebih mendesain bahan tambahan atau teknik-teknik inovatif yang dapat meningkatkan aktivitas (interksi dengan siswa dan guru), serta memperkecil persentasi siswa yang melakukan aktivitas yang tidak relevan dengan kompetensi yang akan dicapai.

b. Role Playing diharapkan sering dilaksanakan pada model pembelajaran bahasa, khususnya Bahasa Inggris, mengingat manfaat Role Playing dapat membantu siswa menguasai penggunaan bahasa dan meningkatkan aktivitas belajar siswa.

c. Role Playing merupakan model pembelajaran yang menarik. Sejalan dengan itu diharapkan mata pelajaran selain bahasa, bisa menerapkannya dalam proses pembelajaran. d. Guru Bahasa diharapkan memiliki motivasi yang tinggi untuk meningkatkan kemampuan berbahasa siswanya dengan menggunakan banyak model pembelajaran, yang membuat proses pembelajaran lebih menarik dan siswa merasa senang sehingga tujuan pembelajaran dapat tercapai secara optimal.

\section{DAFTAR RUJUKAN}

Aqib, Z., (2006), Peneltian Tindakan Kelas. Yrama Widya, Bandung Kunandar., (2007), Guru Profesional, Penerbit Grafindo, Jakarta.

Nurhadi, (2006), Pendekatan Kontekstual, DEPDIKNAS, Jakarta.

Sagala, S., (2009), Konsep dan makna Pembelajaran, Alfabeta, Bandung.

Sanjaya, W., (2006), Model Pembelajaran Berorientasi Standar Proses Pendidikan, Kencana, Jakarta.

Sardiman, A. M., (2008), Interaksi dan Motivasi Belajar Mengajar, Raja Grafindo Persada, Jakarta.

Slameto. (2003). Belajar dan FaktorFaktor yang Mempengaruhinya. Jakarta : Rineka Cipta.

Sudjana, N.,(2005), Penilaian Hasil Proses Mengajar, Penerbit PT Rosdakarya, Bandung

Usman, Uzer., (2004), Menjadi Guru Profesional, Penerbit Remaja Rosdakarya, Bandung. 